Article

\title{
From Waste to Product: Circular Economy Applications from Sea Urchin
}

\author{
Federico Zilia $^{1}$, Jacopo Bacenetti ${ }^{1, * \mathbb{D}}$, Michela Sugni ${ }^{1} \mathbb{D}$, Agata Matarazzo $^{2}(\mathbb{D})$ and Luigi Orsi $^{1}(\mathbb{D})$ \\ 1 Department of Environmental and Political Science, University of Milan, 20133 Milan, Italy; \\ federico.zilia@unimi.it (F.Z.); michela.sugni@unimi.it (M.S.); luigi.orsi@unimi.it (L.O.) \\ 2 Department of Economics and Business, University of Catania, 95131 Catania, Italy; amatara@unict.it \\ * Correspondence: jacopo.bacenetti@unimi.it
}

Citation: Zilia, F.; Bacenetti, J.; Sugni, M.; Matarazzo, A.; Orsi, L. From Waste to Product: Circular Economy Applications from Sea Urchin. Sustainability 2021, 13, 5427. https:// doi.org/10.3390/su13105427

Academic Editor: Pekka Jokinen

Received: 27 March 2021

Accepted: 4 May 2021

Published: 12 May 2021

Publisher's Note: MDPI stays neutral with regard to jurisdictional claims in published maps and institutional affiliations.

Copyright: (c) 2021 by the authors. Licensee MDPI, Basel, Switzerland. This article is an open access article distributed under the terms and conditions of the Creative Commons Attribution (CC BY) license (https:// creativecommons.org/licenses/by/ $4.0 /)$.

\begin{abstract}
The classic linear economy model based on extraction, processing, production and waste no longer seems to be functional in a world where natural resources are starting to run out. For these reasons, the aim of this study is to analyse the transition from a linear system to the circular economy, providing an example of reuse of sea urchin waste for the creation of new eco-sustainable products. From a comprehensive literature review, it is provided a framework of all the properties deriving from marine collagen and other inedible parts of the sea urchin. Thanks to its characteristics, marine collagen is a valid support for production of biomedical devices, dermal implants, cosmetic and pharmaceutical products. To make their core business effective, companies should not consider only the financial perspectives but also the social and environmental aspects. Therefore, this work aims at analysing these three frameworks using the Triple-Layered Business Model Canvas, which is a useful tool to support the creative exploration of sustainable and innovative business models. The reuse of sea urchin waste is a clear example of how a circular economy model can be adopted for companies to be successful. Through this virtuous model, they can be projected towards a green economy based on a more eco-sustainable vision.
\end{abstract}

Keywords: circular economy; sustainability; food waste management; marine collagen; TripleLayered business model

\section{Introduction}

In the last decade, circular economy (CE) has become one of the most discussed issues in the European and non-European political debate [1], as a result of continuous and increasingly evident phenomena related to climate change and the growing emissions of greenhouse gas (GHG) [2].

The traditional linear economy model based on extraction, processing, production and waste no longer seems to be functional in a world where natural resources are starting to run out [3].

According to the United Nations, the world population will reach 9 billion by 2050, causing several problems in terms of food security and in the increasing consumption of raw materials [4]. Therefore, rulers are called upon to pay attention to alternative forms to reduce pollution and waste of these resources, thus inserting the topic of circular economy in the political agenda [1,3,5]. Sustainable economic growth has several purposes: mitigate price volatility, improve food security in the poorest regions of the planet, limit waste of resources, reduce environmental impact and create new jobs [6]. Indeed, precisely with regard to the last point, according to the Environmental Services Association (ESA), the circular economy in the United Kingdom has encouraged the hiring of about 50,000 new jobs and USD 12 billion in investments [7]. In this context, in 2015 the European Commission (EC) introduced the First Action Plan in its agenda with the aim of helping Europe in a process of transition from the linear to the circular economy [8]. The Action Plan provides for 54 measures that seek to close the life cycle of products: from production to 
consumption and waste management [9]. A further step forward was taken by the EC last March 2020, with the adoption of the European Green Deal [10]. This aims to achieve climate neutrality in Europe by 2050, restore biodiversity and incentivize a society that is balanced with a clean and cost-efficient circular economy $[8,10]$. In addition, the Green Deal is committed to supporting the supply, the use of renewable energy sources, by-products and the reuse of waste and residues [11].

In many countries, without contribute from the legislator (e.g., subsidy, frameworks, taxes, etc.), an autonomous and convinced awareness on the part of citizens in adopting initiatives to contrast climate change is still missing. It is therefore necessary to rethink the world economic system in a new perspective, which makes eco-innovation and better food waste management its strengths.

Regarding to this latter aspect, FAO estimates that about 1.3 billion tonnes of food are lost or discarded every year, equal to one third of total edible food [12]. Nowadays, with the increase in fish consumption, most wild fish stocks are classified as fully exploited, with several species facing extinction [13]. Moreover, a remarkable share of waste is represented by the discarded fish, which includes many species and by-catches [14]. Fishing waste is estimated to exceed 20 million tonnes each year, about $25 \%$ of the annual world harvest $[14,15]$. Therefore, this is an increasingly emerging problem, even because fish industries are suspected of being responsible for significant risk to the environment [16]. The fish waste occurs for several reasons: products that are caught but not sold because they have a low commercial value [14], damaged goods, inadequate management of the supply chain, improper storage of the product and finally waste deriving from domestic consumption. There are also species such as sea urchins, where waste is abundant due to the high content of inedible parts, such as shells, spines and viscera [17]. Lacking management of fish waste and overfishing have several negative implications on ecosystems and the protection of marine species (e.g., damage to habitats, illegal fishing, endangered fish species). Therefore, from food waste, the reuse of discarded fish represents a valid tool to reduce the environmental impact of fishing [14] and to promote new forms of sustainable business through more virtuous economy. In addition to better waste management and the reuse of waste to obtain biomaterials or energy sources, by implementing a circular economy approach it is also possible to maximize the value of food production and to reduce waste [18].

Therefore, this study aims to provide concrete examples of circular economy such as the creation of new products deriving from sea urchin waste and the sustainable transition in the sea urchin industry.

The manuscript is organized as follows: Section 2 provides a literature review of the key topics of the article such as the concept of circular economy and waste management, through an integrated model. Section 3 provides a brief description of the global sea urchins trade and the reuse of waste in several sectors such as biomedicine, cosmetics and pharmaceuticals. It will be analysed also the potentials deriving from marine collagen extracted from sea urchin waste. Section 4 broadly analyses the concept of business models in the literature, focusing on the Business Model Canvas methodology applied to companies that process sea urchins. Section 5 provides a Triple-Layered analysis for the sea urchins industry's transition, focusing on the main items that make up the environmental and social layers. Section 6 offers some summary elements.

\section{Theoretical Background}

\subsection{Circular Economy Concept Overview}

Today, the consequences caused by human activities exceed the resilience of ecosystems around the world [19]. Therefore, in recent years, a greater awareness is emerging in making efforts to implement a transition into a circular economy system [19]. Consequently, the discussion on the circular economy is attracting wide interest not only at the political and public debates, but also in the academic literature [4]. Indeed, there are many articles in the literature that try to define and explain the concept of circular economy. The origin 
of the term "Circular Economy" dates back to the late 1970s when Stahel and Reday [20] conceptualized a cyclical economy that could be able to limit waste, increase jobs and ensure the efficiency of natural resources.

Other scholars, like Ghisellini et al. (2016) [21] attributed the concept of circular to Pearce and Turner (1989). For these two economists, natural resources are able to influence the economy in providing inputs for production and consumption and outputs in the form of waste [22]. To explain the circular model, they started by analysing the characteristics of contemporary linear and open-closed economic systems in which production, supported by capital goods, is aimed at the production of goods of consumption, whose ultimate goal is to create utility [23].

To explain the transition from an open-closed to a circular system, it's important to understand the link that exists between used resources and residual waste [23].

As the first law of thermodynamics states, that is, the energy and matter considered, remain constant in a closed system, it is also true in a circular economic system, in which the amount of waste generated in a given period must correspond to the quantity of depleted resources, so as to avoid failing [23]. In contrast to the linear open-ended system, capital goods in the circular model play a temporary role as resources for the production processes [23], but after being consumed they turn into waste. Consequently, if it is considered the recycling factor, a part of the waste can be transformed into resources, thus starting a new production cycle.

However, according to Georgescu-Roegen [24] not all waste can be recycled because of the second law of thermodynamics-entropy. Indeed, the process of recycling and recovering waste materials requires additional energy [24]. This recovery will never be total, but will produce other waste or collateral products [25]. For this reason, even the circular economy shows limits, specifically that of dissipating materials that are lost in the ecosystem and which are then impossible to recover [25]. A solution to this problem, at least in theoretical part, could be to always use renewable energy from the sun, for the entire recycling process. This solution, however, would require large investments and a lot more work to complete the whole cycle.

To better understand the concept of circular economy and its operating principles, it has been possible to find in the literature several reports and articles concerning the $\mathrm{CE}$, published over the years by the Ellen MacArthur Foundation.

The most recent and recurrent definitions are the following: "an industrial economy in which material flows keep circulating at a high rate without entering the biosphere unless they are biological nutrients" [26]; "an industrial economy that is restorative by intentions; aims to rely on renewable energy; minimizes, tracks and eliminates the use of toxic chemicals; and eradicates waste through careful design" [27]; "an economy that provides multiple value-creation mechanism which are decoupled from the consumption of finite resources; in a circular economy, growth comes from "within", by increasing the value derived from existing economic structures, products and materials" $[28,29]$.

Since the circular economy is not yet a common economic model because of application limits, already mentioned, it therefore remains a widely debated topic by economists and academics. However, among the most optimistic visions, the circular economy seems to have a win-win-win potential for three dimensions of sustainable development: economic, environmental and social [25]. In an idealized situation, the physical flows of materials and energy recovered in the CE model would allow to reduce the use of new virgin materials, energy inputs, waste management costs and its output [30]. Consequently, there would be a bunch of cascaded benefits, from reducing raw material and energy costs, to the diversification of reuse along the value chain. This effect is called the "power of cascaded use" [6]. In addition, this power would help to stimulate new job opportunities and growth in the sense of community, with a company projected towards a sharing economy and eco-friendly vision. 


\subsection{From Waste Management to Circular Economy}

To counter the increase in the volume of solid waste produced every year and to limit the negative externalities that derive from it, in the last two decades, many governments have adopted regulations and political decisions aimed at safeguarding their citizens. This awareness led to the Paris Agreement on Climate Change, reached at the end of the 21st Conference of the Parties of the UNFCCC (COP21) in December 2015 [31].

In addition to this, several governments have implemented policies and regulations that force companies to improve their waste management strategies. However, some concerns are still present. Indeed, some companies, transforming part of solid waste to obtain new products, have encountered flaws in the final product so that they did not comply with the RoHS (Restriction of Hazardous Substances Directives) Community legislation. For example, the Swiss watch company "Swatch" had to pay USD 1 billion in 2006 to withdraw from the market and fix several products that had defects in the solder of lead-free tin whiskers, materials previously recovered from other products no longer used [32].

To minimize solid waste production, different solutions can be adopted. First, the traditional hierarchy of waste management from the best choice to the least favourable one. It is a traditional model of waste management based on hierarchic form, represented by an inverted pyramid, which aims to find the solutions that best produce benefits for both human and the environment. The optimal choice to adopt is prevention, while the least favourable option is disposal [33]. In the middle there are a series of other steps that refer to the 3Rs principle, previously mentioned.

Second, the transition from hierarchical waste management to the circular approach is based on three guiding keys: sale, disposal and preparation [34].

To ensure that companies can continue to maximize profits by reducing waste and consumption, they should sell the discarded materials to other companies that deal with the recovery of these products. For example, General Motors located in Detroit (Michigan), by reselling goods, made in part from products previously discarded by other companies, is able to earn USD 1 billion a year from this operation [35].

Furthermore, it is essential to implement green supply chain management to maximize the use of resources and thus reduce, to the point of eliminating, the consumption of new ones [36]. This eco-efficient approach, often considered a circular economy synonymous [37], improves the security of resources and the reduction in emissions and waste [26]. In addition, creating an eco-efficient system, with a better design, allows to reduce costs and eliminate all those excess components, such as reducing packaging to the essential [6]. Finally, it should be noted that companies in recent years have become increasingly aware and prepared with respect to public opinion and legislation on sustainable economics [34] For these reasons, it is important that firms continue to be proactive and prepared in waste management, also through the collaboration of all the skills responsible for the production of the goods, from its design to its complete realization [34].

The environmental challenges that human must face in the short term are many and the circular economy remains the best possible choice so that our system still supports the supply of solid waste.

\section{From Marine Waste to New Eco-Friendly Products: Development of the Biomedicine, Pharmaceuticals, Cosmetics and Blue Biotechnologies \\ 3.1. Global Sea Urchin Harvest and Trade}

Trying to provide an overview about the world sea urchin production and trade, it should be noted that most of the harvest-specifically the gonads of both sexes called roe-occurs in temperate regions of the world.

As can be seen in Figure 1, from 1950 to 2018, the trend of world sea urchin production followed two different performances. The first, growing, from 1950 to 1995, the year in which the harvest reached its peak with 117,039 tonnes of catch. The second, on the other hand, is constantly decreasing, from 1995 to the most recent years. 


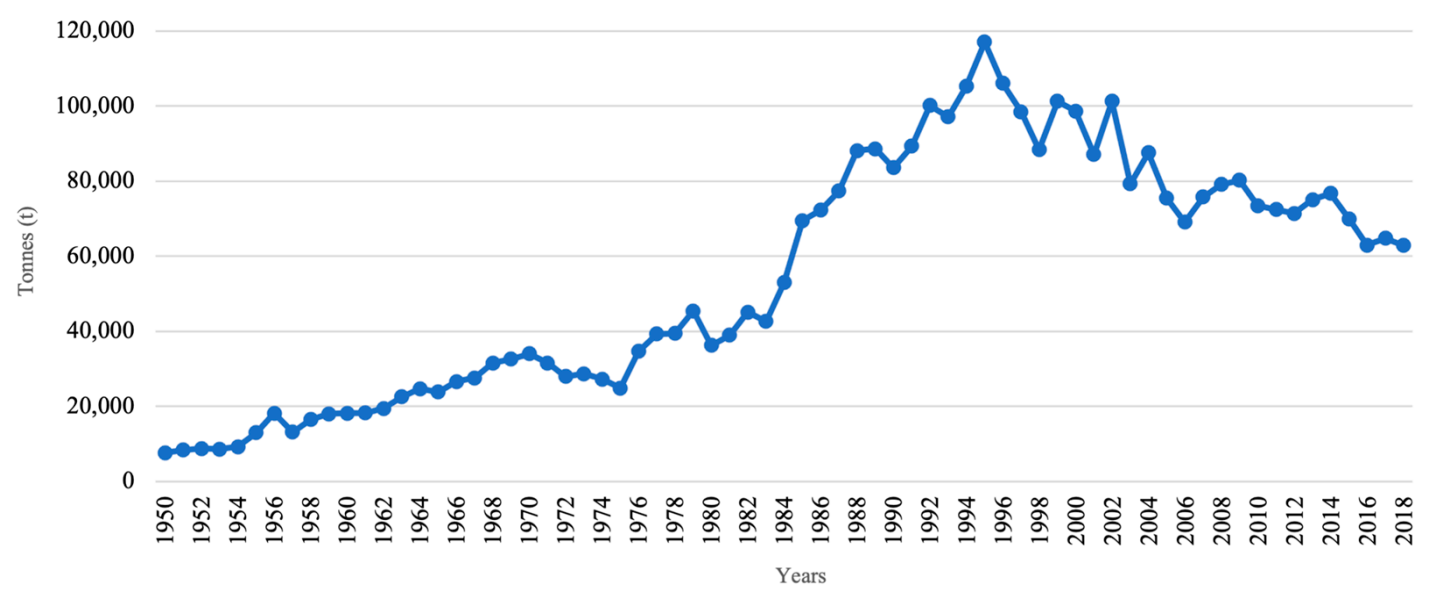

Figure 1. Total world sea urchin production (1950-2018), in tonnes value. Source: authors using FishStatJ database, 2021.

According to the latest available FAO data, indeed, the capture production of sea urchins in 2018, for the species included in the database and in all forms of sale-live, fresh, chilled or frozen-was approximately 62,828 tonnes [38].

Specifically, considering the production by country shown in Figure 2, Chile is the dominant producer of sea urchin, although its production has dropped drastically over the last 18 years, from 54,097 tonnes in 2000 to 30,446 tonnes in 2018 [38].

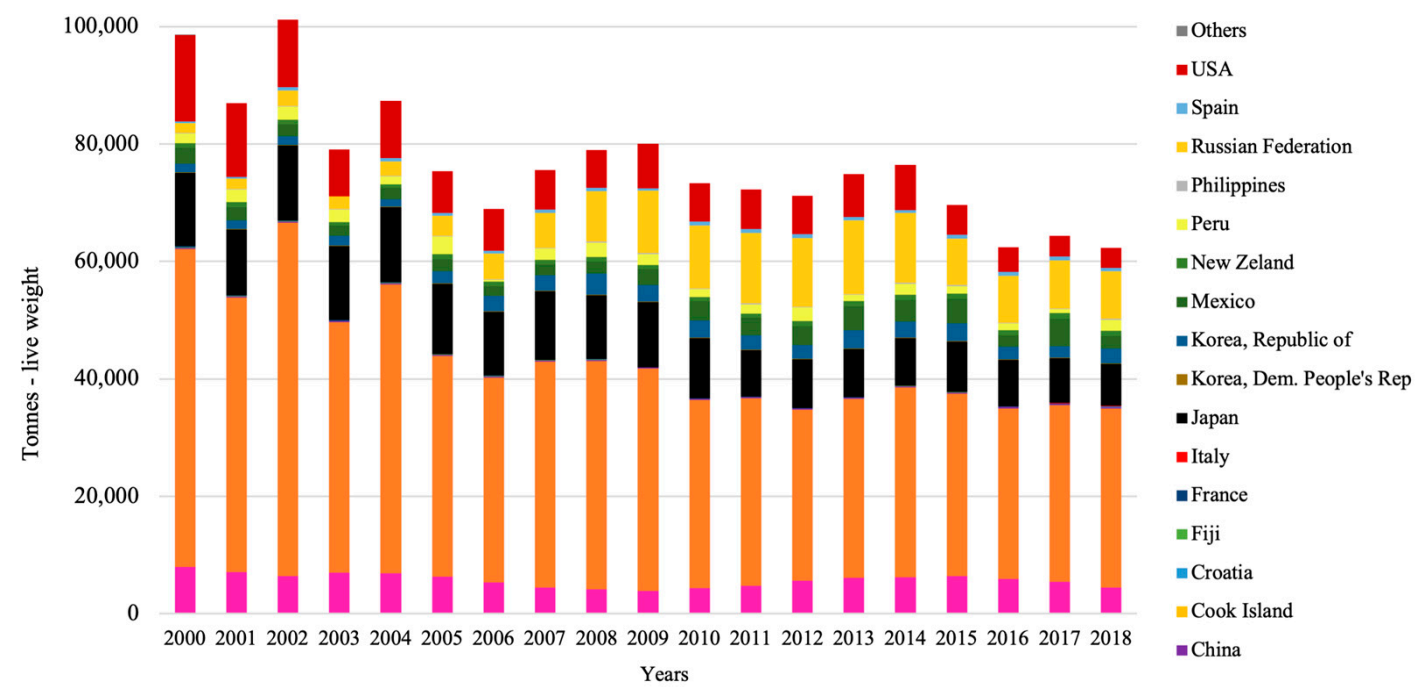

Figure 2. Global Sea Urchins harvest (production) divided by countries (2000-2018), in tonnes value. Source: authors' own elaboration using FishStatJ database, 2021.

Countries such as Japan, USA and Canada have instead maintained a relatively stable trend, while the Russian Federation is one of the few countries to have increased its harvest in recent years, if compared with the early 2000 s.

\subsection{Strategies for the Prevention and Reuse of Fishing Industry Waste}

Over the past two decades, the production and the global demand for fish products have both grown steadily, with an increasingly important role for the aquaculture sector. As shown in Figure 3, the global capture increased from 19 million tonnes in 1950, to more than 97 million tonnes in 2018, while aquaculture production marked an exponential increase, from 638,457 tonnes in 1950, up to 114 million tonnes in 2018 [38]. 


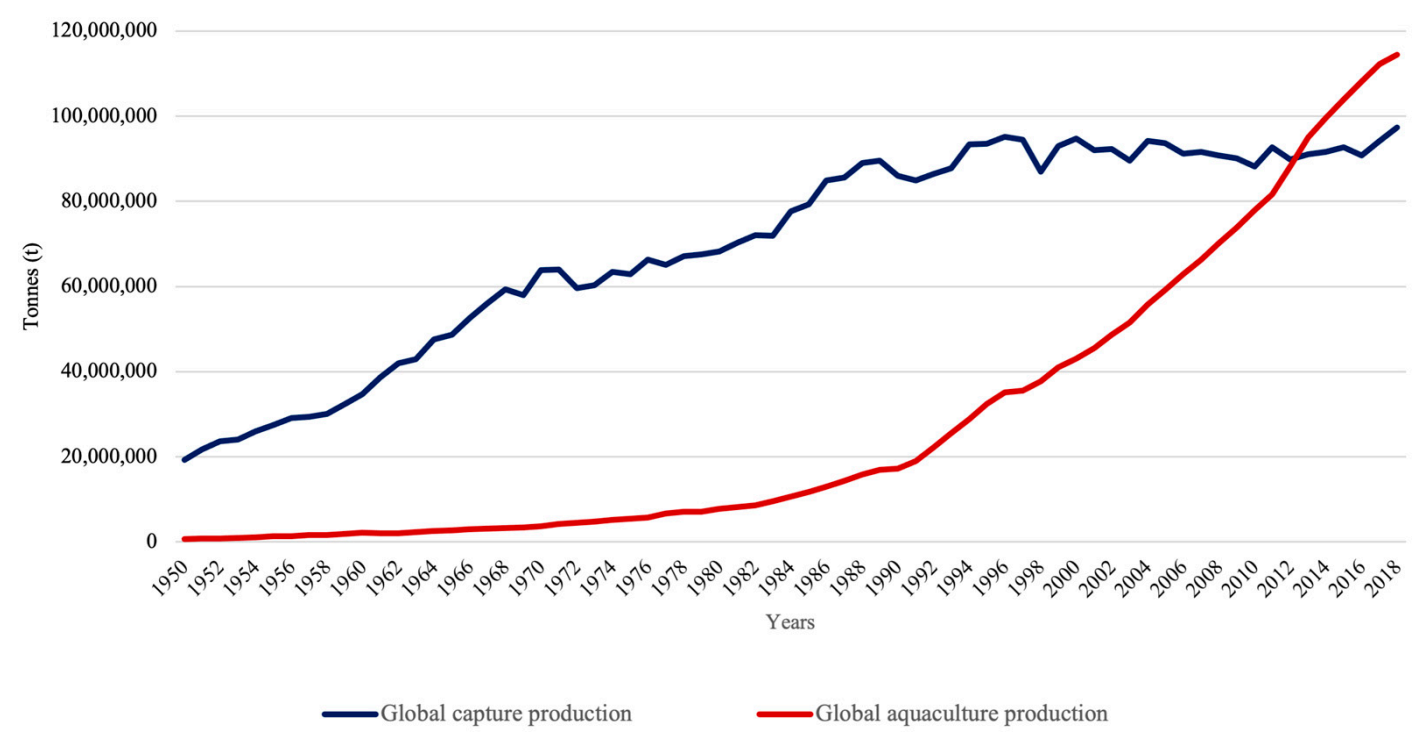

Figure 3. Global capture and aquaculture production (1950-2018), in tonnes value. Source: authors' own elaboration using FishStatJ database, 2021.

However, this growing trend causes an increasing share of waste generated by the processing these products [39]. Specifically, bony and cartilaginous fish and some other species belonging to the Echinoidea class, such as sea urchins, produce a considerable amount of waste from the removal of roe for sale and from large quantities of discarded tests [40,41]. Part of this waste is then reused in different fields, such as animal feed given the protein intake of fish [42], but most of the waste is not reused, thus causing environmental damage [43].

According to FAO, in the most industrialized regions such as Europe, North America and Asia, the main loss of fish and seafood derives from fisheries production, with discard rates between $9-15 \%$ of sea catches [44]. Furthermore, a large part of the purchased product is also wasted by consumer households [44]. In developing countries, on the other hand, the main phases that generate greater waste of fish and seafood are those linked to postcatch activities and product processing [44]. This is mainly due to technological deficiencies and less skilled workers, present in the underdeveloped regions, which thus cause a faster deterioration of goods and greater waste during the transformation phase of the product.

As it has been shown, fish and seafood, but more generally food, are wasted along the entire food supply chain (FSC), from the early stages of harvest and production of the product, to processing and distribution, up to consumption at the domestic or HORECA activities [12].

To avoid excessive waste and the increase in refuse, which risks becoming uncontrolled with the grow in demand and the demographic increase of the population, FAO suggests and encourages sector operators to implement prevention strategies.

Among these, cooperation between producers could be very useful to avoid overproduction-that is, the situation that occurs when the supply on the market exceeds the demand. In this case, the excessive production of one company could solve a shortage of the harvest of another, thus avoiding the exploitation of other new inputs [45], which would then risk remaining unsold and therefore discarded.

Another achievable option is to increase market surveys on consumer preferences in supermarkets. Indeed, some past studies show that consumers are more likely to buy new diversified products, as long as they are qualitatively of high standards and not modified in taste [45]. The market research tool can therefore be a valuable support for companies in understanding and directing their production based on consumer demand and preferences, so as to minimize waste or the accumulation of unsold goods.

In addition, governments, especially those in developing countries, should invest more in infrastructure and transport [46], giving companies incentives to further develop 
storage and cold chain facilities, the latter essential for the conservation of products such as fruit, vegetables, meat and fish [45]. Moreover, in recent years, some researches have been promoted to study how to convert waste into useful products or to be reused in several applications, so as to reduce the negative externalities deriving from the fishing sector, for humans and the environment [16] and to implement a virtuous model of circular economy.

\subsection{The Applications of Marine Collagen Extracted from Sea Urchin Waste in the Biomedicine and} the Pharmaceutical Sector

Skin lesions such as ulcers, wounds and burns are among the most frequent problems in human health care and therapies to treat these critical issues require very expensive economic interventions [47]. To date, different types of skin lesions can be treated with techniques that are not free from serious limitations and dangers, such as immune rejection in allogeneic skin graft, the onset of infections or the presence of scars [48].

To face these problems, in recent years, many researchers have studied and tested marine collagen as a biomaterial [49]. Indeed, it is promising because it is abundant [50], easy to find and biocompatible. Marine collagen is very similar to the collagen present in human tissues, such as bones, blood vessels, ligaments and skin [17]. As for the currently used mammalian source (bovine, equine, pig), most marine collagen is obtained after hydrolysis, a process that partially "destroys" the molecular structure, thus reducing its mechanical strength [51-53]. The positive aspect of sea urchin collagen is that it is obtained without the need of destructive methods [51] and this allows to preserve its structural integrity and therefore mechanical performance, a fundamental element in biomaterial design.

Marine collagen is also widely used in dentistry and generally utilized as a membrane in periodontal and implant therapy, but also in bone grafts [54].

Moreover, thanks to the skin's reparative properties, marine collagen is also used by cosmetic companies for the creation of products containing bioactive ingredients and marine collagen extracts [50], capable of providing benefits, such as the inhibition of photoaging of the skin [55]. Photo-aging, also known as dermatoheliosis, involves skin changes due to sun exposure, ultraviolet (UV) radiation and other external environmental attacks, such as harmful products and sudden changes in temperature $[55,56]$. Therefore, this aspect is very important because in recent years it has been attracting more and more interest both in the field of research and in that of consumption.

Another benefit of marine collagen used for cosmetic products is the fact that this element has a limited smell compared to collagens derived by other animals [56]. Then, moisturizing and elasticizing effects of the skin are also evident using body lotion or serums containing marine collagen, which in the long run cause a firming skin effect [57].

The collagen extracted from sea urchin represents a valid help in reducing waste from the food industry of restaurants and fish companies, thus giving a high value to sea urchin by-products and waste, through a circular economy model [50].

According to recent scientific studies, it is a promising biomaterial for biomedical applications and for these reasons, blue biotechnologies represent an important starting point for a more sustainable future in waste management [49].

\section{Methodology}

\subsection{Business Models}

In the literature there are different definitions of business models and despite several efforts conducted in recent decades, scholars do not seem to have define a single widely recognized definition [58]. Already in the pre-industrial era, business models were a fundamental part of commercial and economic behavior [59]. However, according to Teece (2010), since the 1990s with "the Web revolution" business models have gained wide interest among scholars, as demonstrated by the large number of publications of books and scientific articles on this topic [60]. According to Belussi et al. (2019) after 2005, annual scientific publications relating to business model concepts reached 100 units [61]. 
With the development and spread of the internet, traditional industries, such as DVD rental businesses, had the opportunity to transform their business models to access the online market [59]. Indeed, in the internet sector research demonstrated greater interest to $e$ business models [60]. This term refers to companies that carry out commercial transactions on the internet both with economic partners and with their buyers [62]. Online platforms have not only made it possible to display a product or service to the costumer, but also allowed the development of new possibilities in creating and providing value [60]. This revolution encouraged companies to take new paths in the design of business models useful for delineating new boundaries and alternative organizational approaches of business [63].

As underlined by a general literature review, the business model is defined as a statement [64], representation [65,66] a structural template [60] and a pattern [67].

Specifically, among the most cited definitions of BM, according to Zott and Amit (2010), a business model describes "the content, structure and governance of transactions designed so as to create value through the exploitation of business opportunities" [68], while according to Chesbrough and Rosenbloom (2002), a business model is "the heuristic logic that connects technical potential with the realization of economic value" [69]. As stated by Magretta (2002), business models are "stories that explain how enterprises work. A good business model answers Peter Drucker's age old questions: Who is the customer? And what does the customer value? It also answers the fundamental questions every manager must ask: How do we make money in this business? What is the underlying economic logic that explains how we can deliver value to customers at an appropriate cost?" [70]. Moreover, as argued by Teece (2010) a BM is "how the enterprise creates and delivers value to customers and then converts payments received to profits" [59].

\subsection{An Analysis of Sea Urchin Industry through Original Business Model Canvas}

Given the high flexibility of the business models applied in several sectors, there are different ways to view the BMs [71]. It can be structured in textual description modes such as company reports and brochures useful to provide a detailed focus on the company's finances [72]. Other scholars like Osterwalder (2004) defined the business model as an architecture [73] consisting of elements and relationships organized at different levels [74]. In these terms, the business model assumes a logic of "how an organization creates, provides and captures value" [75]. The "Business Model Canvas" conceived by Osterwalder and Pigneur (2010) is a way to graphically represent the value created by the relationships established between the components of an organization [71].

The Business Model Canvas is a valid economic-financial tool based on 3 key aspects. Firstly, it helps to explain how the different components and parts of a company can integrate to provide value to the customer. Furthermore, this scheme, made up of strategies and interconnections, serves to outline the links between the supply chain and the stakeholder networks [76]. Finally, the BMC explains how from these interconnections it is possible to generate value in the production of a good, thus implementing the company's profits [76]. It is divided into nine blocks [75]: key partners, key activities, key resources, value proposition, customer relationships, customer segments, distribution channels, cost structure and revenue streams. These items can be grouped into four main areas activities: supply, customer infrastructure and finance [75]. However, the core business for companies that process sea urchins is given by:

Value Proposition

What value is the organization delivering to its customers? Which customer painpoints are the organization addressing? [75]. The value proposition (VP) is the most relevant item of BMC because it explains the benefits created by the company in selling a product to its customers and why they should prefer that firm over other companies that provide similar products or services [77]. The VP aims to "address to the specific needs of one or more groups of end users and provide a clear explanation of how these needs will be met, indicating the package of products and services offered to each user" [78]. In this specific case study, the value proposition of a sea urchin industry is the realistic promise 
made to its customers in providing fresh or processed sea urchins, harvested directly from national seas, thus ensuring high quality standards of the goods sold throughout the supply chain (Figure 4). This motivation should persuade a specific target of customers to prefer products from this company over the competition of others. However, it is important that the value proposition is credible and understandable to the consumer, who, together with his personal motivations and needs, is the real key player.

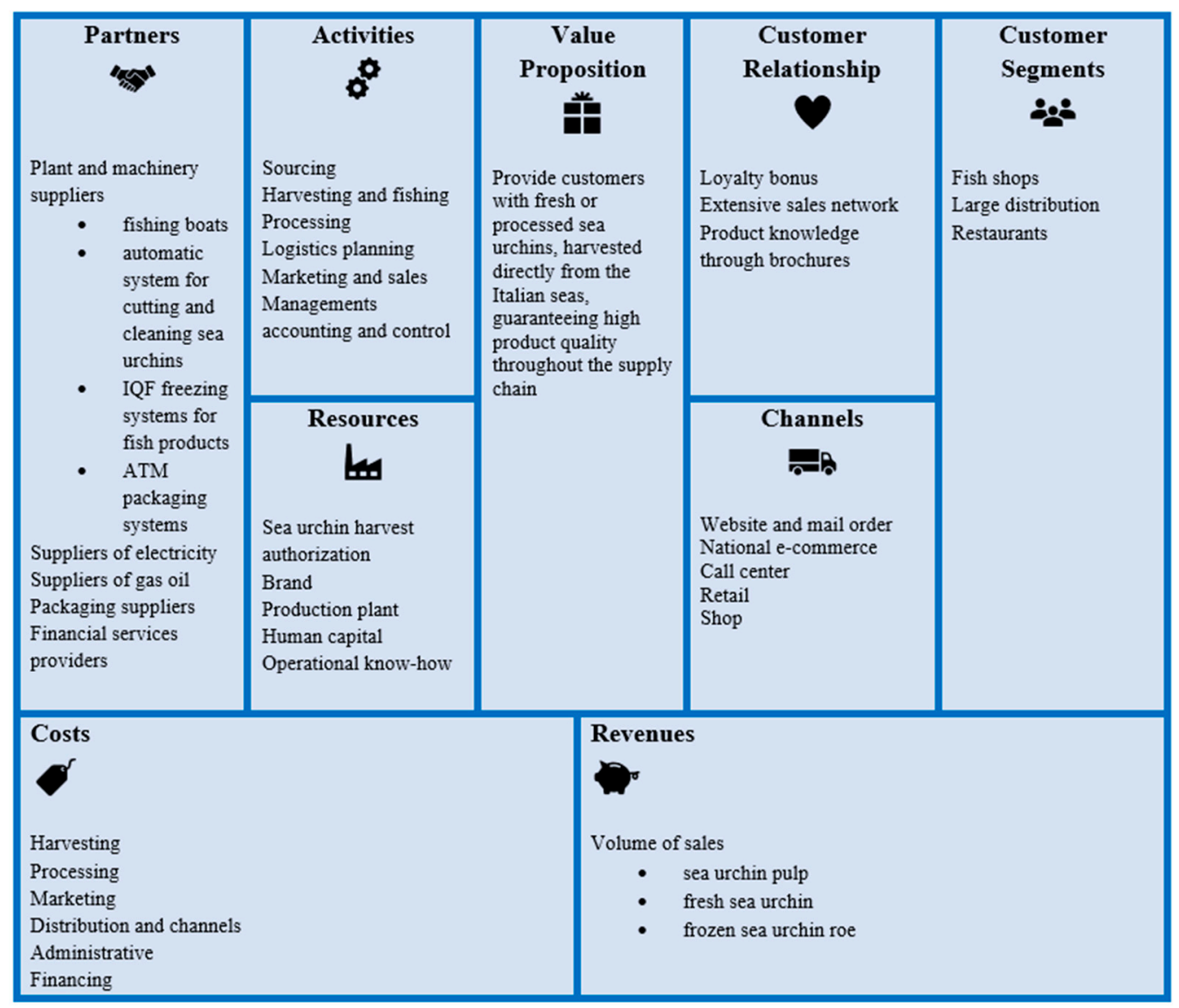

Figure 4. Economic Business Model Canvas. An analysis of the sea urchin industry from an economic point of view. Source: authors' own elaboration, 2021.

\section{Cost Structure}

What are the most important costs inherent in the business mode? Which key resources and activities are most expensive? [75]. The costs structure are the fixed and variable costs that the company must consider for financing the resources, activities and main partners. Among the main fixed costs, the firm must include the rental of plants or machinery and the payment of the salaries of its employees. Instead, variable costs depend on the volumes of goods produced. In this case, for example, the costs due to the harvesting of a certain quantity of sea urchins are included. As it can be imagined, during the sea urchin harvest season, not all fishing trips produce the same results, so the costs in this case can be considered variable. The company must therefore be able to plan in detail all fixed and variable costs so as to set a price on the goods sold that is at the same time competitive in the market and capable of generating profits.

\section{Revenue Streams}

For what value the customers really willing to pay? How do they prefer to pay? How are they currently paying? How does each stream add up to the total revenue, i.e., asset sale, subscription fees, leasing, licensing, advertising, etc.? How much does each Revenue Stream contribute to overall revenues? [75]. Revenue streams indicate the earnings obtained 
from selling products to a specific customer segment. The sea urchin industry generates revenues depending on the volume of goods sold, such as fresh sea urchins, processed pulp, or frozen roe, but also for the way in which customer payments are made (Figure 4).

However, despite the BMC being a very popular tool used by companies, the main purpose of this business model is economic [79], as highlighted precisely by the financial items of cost structure and revenue streams. In addition, BMs need integrations to respond to the increasingly emerging sustainable business prospects [71]. According to Schoormann et al. (2016), there are alternative approaches that extend the traditional BM to include sustainable aspects [71]. One of the most recent integrations is presented by Joyce and Paquin (2016) with their model called "Triple Layered Business Model Canvas" (TLBMC). This business model is completed with extra layers for both social stakeholders and environmental life cycles [71].

\section{Results}

\subsection{Sustainable Transition in the Sea Urchin Industry with the Triple-Layered Business Model Canvas}

This study uses the TLBMC which is a tool "to support the creative exploration of sustainable business models and innovations oriented towards sustainability more generally" [76]. In other words, the TLBMC is a valuable tool for companies to better plan the production of innovative products according to an economy model attentive to social and environmental impact. Furthermore, the TLBMC can also integrate with a circular economy system [80] thus offering many advantages for the company that adopts it. Indeed, it can limit its costs by reducing waste, renewing its production with materials that would generally be discarded and establishing a better relationship with customers [80].

This model provides "horizontal" coherence within each canvas to explore the economic, environmental and social values that emerge from the key actions and relationships established by the nine components of each layer [76]. However, there is also a "vertical" coherence that integrates the value creation across the three levels [81]. According to Joyce and Paquin (2016) this logic "supports exploring the alignment of actions and interconnections across the different types of value" [76]. Regarding the vertical logic, starting from the social framework, the alignment of an item of each canvas crosses the corresponding component of the next layer. This approach highlights an alignment of the actions and possible interconnections between the three canvases [81].

\subsection{The Environmental Layer}

The aim of the environmental layer is to analyse the resulting environmental benefits implemented by companies [82]. It is based on Life Cycle Analysis (LCA), essential for mapping the environmental impact (e.g., carbon and water footprint) deriving from a product or service over the entire life cycle [79]. Filling this layer, it is possible to identify the negative and positive externalities on the environment generated by the company's activities.

As in the economic layer, the environmental and social canvases consist of 9 blocks each [76]. Specifically, the environmental layer is made up of the following items: supplies and outsourcing, production, materials, functional value, end-of-life, use phase, distribution, environmental impacts, environmental benefits [76]. Figure 5 summarizes the main results for each block constituting of the environmental layer for companies that harvest and process sea urchins. However, the core of the environmental layer is given by:

Functional Value

In the Life Cycle Assessment, the functional unit indicates the amount of product that is used as a reference for the computations of the flows of materials and energy used in the inbound and outbound system [83]. Instead, the functional value describes the outputs of the company's production process [82]. Moreover, according to Pardalis et al. (2020) the functional value "describes what a product or service offers in terms of physical quantities". The difference between a LCA's functional unit and the functional value is based on the 
different usage [81]. For example, the functional unit of a sea urchin industry is equivalent to $55 \mathrm{~g}$ corresponding to the product contained in a single jar of sea urchin pulp, while the functional value is the total of this content multiplied by the number of customers who have consumed this product over a certain period of time, such as one year.

\begin{tabular}{|c|c|c|c|c|}
\hline $\begin{array}{l}\text { Supplies and } \\
\text { Outsourcing } \\
\text { Electricity for processes } \\
\text { Water for processes } \\
\text { Laboratory consumables } \\
\text { Laboratory equipment } \\
\text { Gas oil }\end{array}$ & $\begin{array}{l}\text { Production } \\
\text { Harvesting } \\
\text { Sea urchin processing } \\
\text { Sorting } \\
\text { Packing }\end{array}$ & $\begin{array}{l}\text { Functional } \\
55 \text { gr of sea urchin } \\
\text { pulp once weekly } \\
\text { multiplied by the } \\
\text { amount of the } \\
\text { consumers over the } \\
\text { period of one year }\end{array}$ & $\begin{array}{l}\text { End-of-Life } \\
\qquad \begin{array}{l}\text { Packaging end-of-life } \\
\text { Product disposal }\end{array}\end{array}$ & $\begin{array}{l}\text { Use Phase } \\
\text { Water for cleaning } \\
\text { Energy for cooking }\end{array}$ \\
\hline & $\begin{array}{l}\text { Materials } \\
\text { Glass and aluminum } \\
\text { jars } \\
\text { Waterproof paper }\end{array}$ & & $\begin{array}{l}\text { Distribution } \\
\text { Ship transport } \\
\text { Truck transport } \\
\text { Logistic centres }\end{array}$ & \\
\hline \multicolumn{2}{|c|}{$\begin{array}{l}\text { Environmental Impacts } \\
\text { Air pollution emissions } \\
\text { - energy consumption } \\
\text { - water consumption } \\
\text { Virgin resources consumption }\end{array}$} & \multicolumn{3}{|c|}{$\begin{array}{l}\text { Environmental Benefits } \\
\text { Reuse of sea urchins waste } \\
\text { Water reuse } \\
\text { Local harvesting of sea urchins, in compliance with national } \\
\text { regulations for the protection of the species } \\
\text { Technologically advanced processing plants (solar panels) } \\
\text { Energy recovery }\end{array}$} \\
\hline
\end{tabular}

Figure 5. Environmental Life Cycle Business Model Canvas. An analysis of the sea urchin industry from an environmental point of view using the triple layered business model. Source: authors' own elaboration, 2021.

\section{Environmental Impacts}

The environmental impact considers and quantifies the ecological cost of the activities carried out by the company [76]. Environmental impacts can be evaluated using a LCA approach [84]. The most recurring environmental costs for a company are related to biophysical measures [85] such as the use of virgin resources, energy and water consumption, $\mathrm{CO}_{2}$ emissions, damage to human health and waste production.

\section{Environmental Benefits}

This section of the environmental business canvas analyses the actions taken by the company in trying to reduce the negative impact on the environment. These efforts can therefore generate benefits for the ecosystem by giving the product a positive ecological value [76]. The main green economy purposes that a company should pursue are:

- the eco-efficient use of resources so as to reduce waste and energy consumption,

- the innovation of products to limit the loss of biodiversity,

- $\quad$ the reuse of discarded products.

In the future, thanks to the continuous and recent research promoted by institutions and scholars, companies that process sea urchins will be able to reuse waste to extract marine collagen creating biomedical devices or cosmetic products. By adopting a circular economy approach, the reuse of sea urchin waste would guarantee several ecological values such as the reduction of solid waste and a limitation on the virgin resources consumed. 


\subsection{The Social Layer}

The Social Layer constitutes the pillar of the social impacts resulting from relations between stakeholders and the company [77]. As stated by Cardeal et al. (2020) this layer describes "the organizational structure and decision-making strategies of the organization". The term "stakeholders" means a series of members or groups capable of influencing the actions of a company [76]. They can be shareholders, employees, suppliers, government agencies, customers, or communities. According to several scholars, also terrorist groups, mass media and poor people can in some way influence the actions of an organization [86]. Therefore, it is evident that the social layer-compared to the business and environmental one-allows greater flexibility of analysis.

Graphically, the social layer is made up of nine components: social value, employees, governance, local communities, societal culture, scale of outreach, end-users, social impacts and social benefits [76]. The core of social layer is given by:

Social Value

Social value is the central point of the social business model canvas and describes the company's mission in trying to create benefits for stakeholders and society [82]. The social value for a company that processes sea urchins is to offer a quality product every day that allows consumers to enhance the well-being and healthy lifestyle. The social value is increased by the fact that the production tries to be respectful of local and national regulations on sustainability. A company that is able, through the narrative, to make both stakeholders and society understand its material and immaterial factors [87], can best express the additional value of its product. Furthermore, the social value aims to improve the skills level of employees, so to generate a positive impact on the promotion of education in the local communities [79].

\section{Local Communities}

Local communities represent a net of relationships between the stakeholders present in the company. A successful company must establish a relationship based on the spirit of collaboration and friendship with local institutions, consumer citizens, suppliers, media and trade unions. Therefore, it is important to establish a relationship of trust with the area, offering job opportunities to young inhabitants in that region, respecting the environment and enhancing local products. Indeed, fish companies are increasingly subject to the analysis of social media and environmental protection authorities. If a company does not have all the environmental credentials this would lead to a loss of consumer confidence [88] and, consequently, of the local community.

Social Impacts

The social impacts include a series of components deriving from the company's activity on human and society. Therefore, it can be considered as a social cost, even if it is not entirely clear which are the most suitable indicators to quantify this impact. According to Benoit et al. (2010), the most useful elements to understand the negative social impact caused by the activity of an organization are the following: actions that violate the fundamental rights of the worker [89] (e.g., working hours, wages, safety in the workplace), corruption, bribes and actions that harm people and the ecosystem [90].

\section{Social Benefits}

According to Pardalis et al. (2020) social benefits are "the positive social value creating aspects of the organization's action". Among the several social benefits caused by the activity of a company is the one related to the creation of new jobs. As shown in Figure 6, employees can follow company update courses, educating themselves and training on specific skills required by the organization [91]. Furthermore, the consumption of fish products like sea urchins, is healthy for the human being. Finally, by reusing the waste obtained from sea urchins it is possible to reach positive results in several sectors such as biomedicine, pharmaceuticals and cosmetics. 


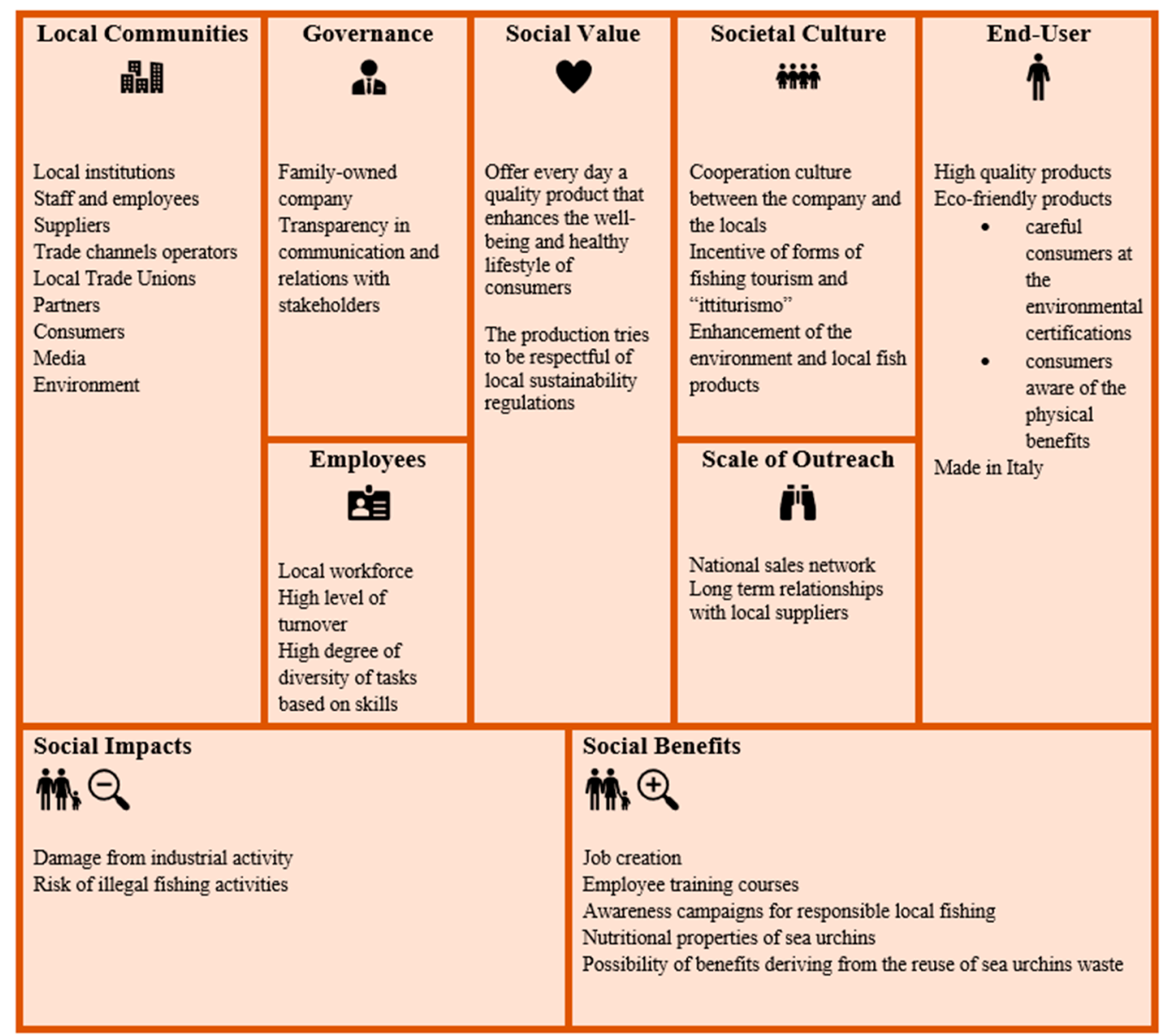

Figure 6. Social stakeholder Business Model Canvas. An analysis of the sea urchin industry from a social point of view using the triple layered business model. Source: authors' own elaboration, 2021.

\section{Conclusions}

Until now, the economy has always operated according to a linear model of "productionconsumption-disposal" linked to the concept of "end-of-life" of a product. In recent decades, with the increase in population and with the growth in demand for resources, often scarce, there are more and more phenomena of environmental decline [18]. Therefore, it is increasingly emerging in the population and in business a desire for sustainable economic growth, to counter the constant increase in the production and consumption of raw materials, which generate negative externalities such as pollution and the accumulation of waste. This new economic system shifts the focus on reusing, fixing, renewing and recycling existing discarded products [29]. Hence, this model moves from considering waste as a new useful resource. To complete this transition from the linear to the circular system, it is required the contribution of all the main actors such as politicians, citizens and entrepreneurs.

Eco-innovations combined with developed business models such as sharing, rental and repair [92], will be able to guarantee companies the creation of new products and markets, thus offering many business opportunities for these firms.

Our analysis has provided some useful market opportunities derived by sea urchin waste. That of the sea urchin market certainly turns out to be interesting and full of potential to be seized. In addition, sea urchin waste can be reused for new innovations in the fields of biomedicine, pharmaceuticals and cosmetics. On an industrial level, collagen is extracted mainly from calf skin and bones, a practice that, however, involves serious risks linked to the transmission of infectious diseases [51]. Vice versa, this study, taking up previously carried out research papers, has showed that the fibrillar collagen of the sea urchin is a safe biomaterial [49]. Indeed, the work has highlighted that sea urchin marine collagen can be applied for the regeneration of damaged or structural skin such as cartilage 
and tendons [17]. Moreover, thanks to its countless properties, marine collagen could be used to prevent gastric ulcers, obesity and other problems such as diabetes [54]. In addition, fishing industry waste can be reused for the biofuels or biogas production [93]. All these innovative forms, often still in the experimental phase, could give important benefits both at a socio-economic and environmental level [93].

The reuse of sea urchin waste is, therefore, a clear example of how a circular economy model, capable of making profits and recycling of waste, can be adopted, thus enhancing the management of food waste and promoting new products to be destined in increasingly and promising markets.

For these reasons, companies should consider the environmental and social layers deriving from their activities, planning a TLBMC, to better focus their core business.

The environmental and social benefits deriving from companies that harvest and process sea urchin in a circular way can be several. The innovative products produced with discarded sea urchins materials can contribute to protect biodiversity, while from a social point of view, the industrial conversion to a circular economy would guarantee new job opportunities [94] for the local community and the possibility to train employees through educational courses useful to build future green manager figure [91].

However, the circular economy requires not only innovative concepts [4], but also the ability of stakeholders to carry out activities as sustainable as possible [95].

Our study has some limitations relating to the TLBMC methodology that would be further investigated. First, the study was conducted by approaching a hypothetical case. Indeed, despite the growing interest in sustainable economic models, the environmental and social implications of the fishing sector are still little explored in the literature [96]. Furthermore, the estimates related to the seafood product are inadequate [96]. The fisheries databases are unable to provide useful information to quantify the environmental impact generated by modern fishing [96]. Although there is a lack of information in the industries that harvest and process sea urchins [97], we have mitigated this problem by trying to outline a scenario that is as plausible as possible through the TLBMC.

Second, the study provides a general analysis of stakeholders who have direct or indirect relationships with companies that process sea urchins. However, this is a theoretical reconstruction, as actually the sea urchin market is varied according to the different producing countries [97]. Future research should be conducted to better understand the key players in the sea urchin supply chain, from the harvest phase to the end-of-life of the product.

Third, as has been pointed out in the methodology, the literature on business models underlines some limitations [74]. Moreover, most of publications are quite recent and often there is a tendency to apply business models in several different sectors [59], thus, raising doubts about the real effectiveness of these structural templates [74]. As explained by Joyce and Paquin (2016), the TLBMC to which our study refers, only provides a "highlevel summer analysis" [76], without going into details. However, despite these strict boundaries [98], this tool provides a general intuitive view of the value creation and activities of the analysed organization [76]. If well integrated with other tools, such as the life cycle analysis, the TLBMC can become a valid aid to underline positive or negative implications [99] deriving from company's activities both in the economic, environmental and social frameworks.

Author Contributions: Conceptualization, J.B. and M.S.; methodology, L.O.; software, F.Z.; writingoriginal draft preparation, F.Z.; writing—review and editing, A.M., F.Z., J.B., M.S. and L.O. All authors have read and agreed to the published version of the manuscript.

Funding: This study was developed by University of Milan under the "Chain for Innovative Recycling: Sea Urchin Food By-Products for Zero Waste-Based Multiple Applications (CIRCULAr)" project, funded by Cariplo Foundation and "By-product Recycling for Innovative Technology from the Sea (BRITEs)" project, funded by MiUR.

Institutional Review Board Statement: Not applicable. 
Informed Consent Statement: Not applicable.

Data Availability Statement: The data presented in this study are available on request from the corresponding author.

Conflicts of Interest: The authors declare no conflict of interest.

\section{References}

1. Monier, V.; Hestin, M.; Cavé, J.; Laureysens, I.; Watkins, E.; Reisinger, H.; Porsch, L. Development of Guidance on Extended Producer Responsibility (EPR); European Commission-DG Environment, 2014; pp. 2-227. Available online: https: / / ec.europa.eu/environment/archives/waste/eu_guidance/pdf/Guidance\%20on\%20EPR\%20-\%20Final\%20Report.pdf (accessed on 7 December 2020).

2. Zafeiriou, E.; Mallidis, I.; Galanopoulos, K.; Arabatzis, G. Greenhouse Gas Emissions and Economic Performance in EU Agriculture: An Empirical Study in a Non-Linear Framework. Sustainability 2018, 10, 3837. [CrossRef]

3. European Commission. Towards a Circular Economy: A Zero Waste Programme for Europe 2014. Available online: https:// eur-lex.europa.eu/resource.html?uri=cellar:50edd1fd-01ec-11e4-831f-01aa75ed71a1.0001.01/DOC_1\&format=PDF (accessed on 9 December 2020).

4. Hamam, M.; Chinnici, G.; Di Vita, G.; Pappalardo, G.; Pecorino, B.; Maesano, G.; D’Amico, M. Circular Economy Models in Agro-Food Systems: A Review. Sustainability 2021, 13, 3453. [CrossRef]

5. European Commission. Closing the Loop-An EU Action Plan for the Circular Economy. 2015. Available online: https://ec europa.eu/transparency/regdoc/rep/1/2015/EN/1-2015-614-EN-F1-1.PDF (accessed on 9 December 2020).

6. Kalmykova, Y.; Sadagopan, M.; Rosado, L. Circular economy-From review of theories and practices to development of implementation tools. Elsevier 2018, 135, 190-201. [CrossRef]

7. ESA. Going for Growth: A Practical Route to a Circular Economy. 2013. Available online: http:/ /www.esauk.org/application/ files/6715/3606/7843/Circular_Economy_Report_FINAL_High_Res_For_Release.pdf (accessed on 16 December 2020).

8. Smol, M.; Marcinek, P.; Duda, J.; Szołdrowska, D. Importance of Sustainable Mineral Resource Management in Implementing the Circular Economy (CE) Model and the European Green Deal Strategy. Resources 2020, 9, 55. [CrossRef]

9. European Commission. Report on the Implementation of the Circular Economy Action Plan; European Commission, 2019. Available online: https:/ / ec.europa.eu/commission/sites/beta-political/files/report_implementation_circular_economy_action_plan.pdf (accessed on 9 December 2020).

10. European Commission. The European Green Deal. 2020. Available online: https:/ / eur-lex.europa.eu/resource.html?uri=cellar: b828d165-1c22-11ea-8c1f-01aa75ed71a1.0002.02/DOC_1\&format=PDF (accessed on 14 December 2020).

11. Raimondo, M.; Caracciolo, F.; Cembalo, L.; Chinnici, G.; Pappalardo, G.; D'Amico, M. Moving towards circular bioeconomy: Managing olive cake supply chain through contracts. Sustain. Prod. Consum. 2021, 28, 180-191. [CrossRef]

12. FAO. The State of Food and Agriculture 2019. Moving Forward on Food Loss and Waste Reduction; Food and Agriculture Organization of the United Nations: Rome, Italy, 2019. Available online: http://www.fao.org/3/ca6030en/ca6030en.pdf (accessed on 11 January 2021).

13. Delgado, C.L.; Wada, N.; Rosegrant, M.W.; Ahmed, M. The Future of Fish. Issues and Trends to 2020; International Food Policy Research Institute: Washington, DC, USA, 2003.

14. Caruso, G. Fishery Wastes and By-products: A Resource to Be Valorised. J. Fish. 2015, 9, 12-15.

15. Kim, S.K.; Mendis, E. Bioactive compounds from marine processing by-products-a review. Food Res. Int. 2006, $39,383-393$. [CrossRef]

16. Arvanitoyannis, I.S.; Tserkezou, P. Seafood Processing: Technology, Quality and Safety; Boziaris, I.S., Ed.; John Wiley \& Sons, Ltd: Chichester, UK, 2014; ISBN 978-1-118-34621-1.

17. Raman, M.; Gopakumar, K. Fish Collagen and its Applications in Food and Pharmaceutical Industry: A Review. EC Nutr. 2018, 13, 752-767.

18. Borrello, M.; Pascucci, S.; Caracciolo, F.; Lombardi, A.; Cembalo, L. Consumers are willing to participate in circular business models: A practice theory perspective to food provisioning. J. Clean. Prod. 2020, 259, 121013. [CrossRef]

19. Borrello, M.; Pascucci, S.; Cembalo, L. Three Propositions to Unify Circular Economy Research: A Review. Sustainability 2020, 12, 4069. [CrossRef]

20. Stahel, W.R.; Reday, G. Jobs for Tomorrow, the Potential for Substituting Manpower for Energy; Vantage Press: New York, NY, USA, 1982; ISBN 0-533-04799-4.

21. Ghisellini, P.; Cialani, C.; Ulgiati, S. A review on circular economy: The expected transition to a balanced interplay of environmental and economic systems. J. Clean. Prod. 2016, 114, 1-47. [CrossRef]

22. Pearce, D.W.; Turner, K. Economics of Natural Resources and the Environment; Johns Hopkings University Press: Baltimora, MD, USA, 1989; ISBN 978-0-8018-3987-0.

23. Andersen, M.S. An introductory note on the environmental economics of the circular economy. Sustain. Sci. 2007, 2, 133-140. [CrossRef]

24. Georgescu-Roegen, N. The Entropy Law and the Economic Process; Harvard University Press: Cambridge, MA, USA, 1971; ISBN 978-0-674-28165-3. 
25. Korhonen, J.; Honkasalo, A.; Seppälä, J. Circular Economy: The Concept and its Limitations. Elsevier 2018, 143, 37-46. [CrossRef]

26. Ellen Macarthur Foundation. Towards the Circular Economy. 2012. Available online: https:/ /www.ellenmacarthurfoundation. org/news/towards-the-circular-economy (accessed on 14 January 2021).

27. Ellen Macarthur Foundation. Towards the Circular Economy. Economic and Business Rationale for an Accelerated Transition. 2013. Available online: https://www.ellenmacarthurfoundation.org/assets/downloads/publications/Ellen-MacArthur-FoundationTowards-the-Circular-Economy-vol.1.pdf (accessed on 15 January 2021).

28. Ellen Macarthur Foundation. Delivering the Circular Economy a Toolkit for Policymakers. 2015, pp. 21-28. Available online: https: //www.ellenmacarthurfoundation.org/assets/downloads/publications/EllenMacArthurFoundation_PolicymakerToolkit.pdf (accessed on 14 January 2021).

29. Ellen Macarthur Foundation. Growth within: A Circular Economy Vision for a Competitive Europe. 2015. Available online: https:/ / www.ellenmacarthurfoundation.org/assets/downloads/publications/EllenMacArthurFoundation_GrowthWithin_July15.pdf (accessed on 14 January 2021).

30. Korhonen, J.; von Malmborg, F.; Strachan, P.A.; Ehrenfeld, J.R. Management and Policy Aspects of Industrial Ecology: An Emerging Research Agenda. Bus. Strategy Environ. 2004, 13, 289-305. [CrossRef]

31. Robbins, A. How to understand the results of the climate change summit: Conference of Parties21 (COP21) Paris 2015. J. Public Health Policy 2016, 37, 129-132. [CrossRef]

32. Jacobsen, K. Within a Whisker of Failure. Guardian 2008. Available online: https://www.theguardian.com/technology/2008 /apr/03/research.engineering (accessed on 12 December 2020).

33. Papargyropoulou, E.; Lozano, R.; Steinberger, J.; Wright, N.; bin Ujang, Z. The food waste hierarchy as a framework for the management of food surplus and food waste. J. Clean. Prod. 2014, 76, 106-115. [CrossRef]

34. Romero-Hernández, O.; Romero, S. Maximizing the value of waste: From waste management to the circular economy. Thunderbird Int. Bus. Rev. 2018, 60, 757-764. [CrossRef]

35. Muller, J. How GM Makes \$1 Billion a Year by Recycling Waste. Forbes 2013. Available online: https:/ /www.forbes.com/sites/ joannmuller/2013/02/21/how-gm-makes-1-billion-a-year-by-recycling-waste/?sh=7987bf522309 (accessed on 4 January 2021).

36. Ying, J.; Li-jun, Z. Study on green supply chain management based on circular economy. Phys. Procedia 2012, 25, 1682-1688. [CrossRef]

37. Wijkman, A.; Skånberg, K. The Circular Economy and Benefits for Society. Swedish Case Study Shows Jobs and Climate as Clear Winners; Club of Rome, 2015. Available online: https:/ / circulareconomy.europa.eu/platform/sites/default/files/the-circular-economyczech-republic-and-poland.pdf (accessed on 13 January 2021).

38. FAO. FishStatJ-Software for Fishery and Aquaculture Statistical Time Series; FAO: Rome, Italy, 2021.

39. MacLeod, J.A.; Kuo, S.; Gallant, T.L.; Grimmett, M. Seafood processing wastes as nutrient sources for crop production. Can. J. Soil Sci. 2006, 86. [CrossRef]

40. Lawrence, J. Edible Sea Urchins: Biology and Ecology, 2nd ed.; Elsevier Science: Amsterdam, The Netherlands, 2006; Volume 38, ISBN 978-0-444-52940-4.

41. Mamelona, J.; Saint-Louis, R.; Pelletier, É. Proximate composition and nutritional profile of by-products from green urchin and Atlantic sea cucumber processing plants. Int. J. Food Sci. Technol. 2010, 45, 2119-2126. [CrossRef]

42. Mo, W.Y.; Man, Y.B.; Wong, M.H. Use of food waste, fish waste and food processing waste for China's aquaculture industry: Needs and challenge. Sci. Total Environ. 2018, 613, 635-643. [CrossRef] [PubMed]

43. Arnesen, J.A.; Gildberg, G. Extraction and characterisation of gelatine from Atlantic salmon (Salmo salar) skin. Bioresour. Technol. 2007, 98, 53-57. [CrossRef]

44. Gustavsson, J.; Cederberg, C.; Sonesson, U.; van Otterdijk, R.; Meybeck, A. Global Food Losses and Food Waste. Extent, Causes and Prevention; FAO: Rome, Italy, 2011.

45. Stuart, T. Waste-Uncovering the Global Food Scandal; Penguin Books: London, UK, 2009; ISBN 978-0-14-103634-2.

46. APO; FAO. Recent Developments in Reducing Postharvest Losses in the Asia-Pacific Region. From: Postharvest Management of Fruit and Vegetables in the Asia-Pacific Region; Asian Productivity Organization: Rome, Italy, 2006.

47. Sen, C.K.; Gordillo, G.M.; Roy, S.; Kirsner, R.; Lambert, L.; Hunt, T.K.; Gottrup, F.; Gurtner, G.; Longaker, M.T. Human skin wounds: A major and snowballing threat to public health and the economy. Wound Repair Regen. 2009, 17, 763-771. [CrossRef] [PubMed]

48. Shahrokhi, S.; Anna, A.; Jeschke, M.G. The Use of Dermal Substitutes in Burn Surgery: Acute Phase. Wound Repair Regen. 2014, 22, 14-22. [CrossRef]

49. Ferrario, C.; Rusconi, F.; Pulaj, A.; Macchi, R.; Landini, P.; Paroni, M.; Colombo, G.; Martinello, T.; Melotti, L.; Gomiero, C.; et al. From Food Waste to Innovative Biomaterial: Sea Urchin-Derived Collagen for Applications in Skin Regenerative Medicine. Mar. Drugs 2020, 18, 414. [CrossRef]

50. Coppola, D.; Oliviero, M.; Vitale, G.A.; Lauritano, C.; D’Ambra, I.; Iannace, S.; de Pascale, D. Marine Collagen from Alternative and Sustainable Sources: Extraction, Processing and Applications. Mar. Drugs 2020, 18, 214. [CrossRef] [PubMed]

51. Di Benedetto, C.; Barbaglio, A.; Martinello, T.; Alongi, V.; Fassini, D.; Cullorà, E.; Patruno, M.; Bonasoro, F.; Barbosa, M.A.; Carnevali, M.D.C.; et al. Production, Characterization and Biocompatibility of Marine Collagen Matrices from an Alternative and Sustainable Source: The Sea Urchin Paracentrotus lividus. Mar. Drugs 2014, 12, 4912-4933. [CrossRef] 
52. Song, E.; Kim, S.Y.; Chun, T.; Byun, H.J.; Lee, Y.M. Collagen scaffolds derived from a marine source and their biocompatibility. Biomaterials 2006, 27, 2951-2961. [CrossRef]

53. Jeong, S.I.; Kim, S.Y.; Cho, S.K.; Chong, M.S.; Kim, K.S.; Kim, H.; Lee, S.B.; Lee, Y.M. Tissue-engineered vascular grafts composed of marine collagen and PLGA fibers using pulsatile perfusion bioreactors. Biomaterials 2007, 28, 1115-1122. [CrossRef]

54. Lim, Y.S.; Ok, Y.J.; Hwang, S.Y.; Kwak, J.Y.; Yoon, S. Marine Collagen as A Promising Biomaterial for Biomedical Applications. Mar. Drugs 2019, 17, 467. [CrossRef] [PubMed]

55. Zhuang, Y.; Zhao, H.H.X.; Zhang, Z.; Li, B. Effects of collagen and collagen hydrolysate from jellyfish (Rhopilema esculentum) on mice skin photoaging induced by UV irradiation. J. Food Sci. 2009, 74, 183-188. [CrossRef] [PubMed]

56. Venkatesan, J.; Anil, S.; Kim, S.K.; Shim, M.S. Marine Fish Proteins and Peptides for Cosmeceuticals: A Review. Mar. Drugs 2017, 15, 143. [CrossRef] [PubMed]

57. Xhauflaire-Uhoda, E.; Fontaine, K.; Piérard, G.E. Kinetics of moisturizing and firming effects of cosmetic formulations. Int. J. Cosmet. Sci. 2008, 30, 131-138. [CrossRef]

58. Moggi, S.; Cantele, S.; Vernizzi, S.; Beretta Zanoni, A. The Business Model Concept and Disclosure: A Preliminary Analysis of Integrated Reports; EuroMed Press: Warsaw, Poland, 2016; pp. 1313-1322.

59. Teece, D.J. Business Models, Business Strategy and Innovation. Long Range Plan. 2010, 43, 171-194. [CrossRef]

60. Amit, R.H.; Zott, C. Value creation in e-business. Strateg. Manag. J. 2001, 22, 493-520. [CrossRef]

61. Belussi, F.; Orsi, L.; Savarese, M. Mapping Business Model Research: A Document Bibliometric Analysis. Scand. J. Manag. 2019, 35. [CrossRef]

62. Mahadevan, B. Business models for Internet-based e-commerce: An anatomy. Calif. Manag. Rev. 2000, 42, 55-69. [CrossRef]

63. Dunbar, R.L.M.; Starbuck, W.H. Learning to Design Organizations and Learning from Designing Them. Organ. Sci. 2006, 17, 171-178. [CrossRef]

64. Stewart, D.W.; Zhao, Q. Internet marketing, business models and public policy. J. Public Policy Mark. 2000, 19, 287-296. [CrossRef]

65. Morris, M.; Schindehutte, M.; Allen, J. The entrepreneur's business model: Toward a unified perspective. J. Bus. Res. 2005, 58, 726-735. [CrossRef]

66. Shafer, S.M.; Smith, H.J.; Linder, J. The power of business models. Bus. Horiz. 2005, 48, 199-207. [CrossRef]

67. Brousseau, K.J.; Penard, T. The economics of digital business models: A framework for analyzing the economics of platforms. Rev. Netw. Econ. 2006, 6, 81-110. [CrossRef]

68. Zott, C.; Amit, R.H. Business model design: An activity system perspective. Long Range Plan. 2010, 43, 216-226. [CrossRef]

69. Chesbrough, H.W.; Rosenbloom, R.S. The role of the business model in capturing value from innovation: Evidence from Xerox Corporation's technology spinoff companies. Ind. Corp. Chang. 2002, 11, 533-534. [CrossRef]

70. Magretta, J. Why business models matter. Harv. Bus. Rev. 2002, 80, 3-8.

71. Schoormann, T.; Behrens, D.; Kolek, E.; Knackstedt, R. Sustainability in Business Models-a Literature Review Based Design Science Oriented Research Agenda; Twenty-Fourth European Conference on Information Systems; Istanbul, Turkey, 2016. Available online: https: / / aisel.aisnet.org / cgi / viewcontent.cgi?referer=\&httpsredir=1\&article=1138\&context=ecis2016_rp (accessed on 14 January 2021).

72. Kanshieva, A. Sustainability-Driven Entrepreneurship as a Tool to Increase Rural Resilience in Russia: Framework for Transfer of the European Experience. Ph.D. Thesis, University of Padua, Padua, Italy, 2012.

73. Osterwalder, A. The Business Model Ontology-A Proposition in a Design Science Approach; University of Lausanne: Lausanne, Switzerland, 2004.

74. Zott, C.; Amit, R.H.; Massa, L. The Business Model: Recent Developments and Future Research. J. Manag. 2011, 37. [CrossRef]

75. Osterwalder, A.; Pigneur, Y. Business Model Generation: A Handbook for Visionaries, Game Changers, and Challengers, 1st ed.; John Wiley \& Sons: Hoboken, NJ, USA, 2010; ISBN 978-0-470-87641-1.

76. Joyce, A.; Paquin, R.L. The triple layered business model canvas: A tool to design more sustainable business models. J. Clean. Prod. 2016, 135, 1474-1486. [CrossRef]

77. Massa, L.; Tucci, C.L.; Afuah, A. A Critical Assessment of Business Model Research. Acad. Manag. Ann. 2016, 11, 73-104 [CrossRef]

78. Giourka, P.; Sanders, M.W.J.L.; Angelakoglou, K.; Pramangioulis, D.; Nikolopoulos, N.; Rakopoulos, D.; Tryferidis, A.; Tzovaras, D. The Smart City Business Model Canvas-A Smart City Business Modeling Framework and Practical Tool. Energies 2019, 12, 4798. [CrossRef]

79. Cardeal, G.; Höse, K.; Ribeiro, I.; Götze, U. Sustainable Business Models-Canvas for Sustainability, Evaluation Method, and Their Application to Additive Manufacturing in Aircraft Maintenance. Sustainability 2020, 12, 9130. [CrossRef]

80. Lahti, T.; Wincent, J.; Parida, V. A Definition and Theoretical Review of the Circular Economy, Value Creation, and Sustainable Business Models: Where Are We Now and Where Should Research Move in the Future? Sustainability 2018, 10, 2799. [CrossRef]

81. Pardalis, G.; Mahapatra, K.; Mainali, B. A triple-layered one-stop-shop business model canvas for sustainable house renovations. IOP Conf. Ser. Earth Environ. Sci. 2020, 588, 022060. [CrossRef]

82. García-Muiña, F.E.; Medina-Salgado, M.S.; Ferrari, A.M.; Cucchi, M. Sustainability Transition in Industry 4.0 and Smart Manufacturing with the Triple-Layered Business Model Canvas. Sustainability 2020, 12, 2364. [CrossRef]

83. Jensen, A.A.; Hoffman, L.; Møller, B.T.; Schmidt, A. Life Cycle Assessment. A Guide to Approaches, Experiences and Information Sources; European Environment Agency: UK, 1997. 
84. Mallard, K.; Debusschere, V.; Garbuio, L. Multi-Criteria Method for Sustainable Design of Energy Conversion Systems. Sustainability 2020, 12, 6513. [CrossRef]

85. Jolliet, O.; Margni, M.; Charles, R.; Humbert, S.; Payet, J.; Rebitzer, G.; Rosenbaum, R. IMPACT 2002+: A new life cycle impact assessment methodology. Int. J. Life Cycle Assess. 2003, 8, 324. [CrossRef]

86. Miles, S. Stakeholder Theory Classification: A Theoretical and Empirical Evaluation of Definitions. J. Bus. Ethics 2017, 142, 437-459. [CrossRef]

87. Milesi, A. Vendere L'immateriale. Intangible Marketing, Marketing Sensoriale, Marketing Narrativo; Guerini Next: Milano, Italy, 2017; ISBN 88-6896-112-1.

88. Ballatore, M. Licenza Sociale a Operare Nel Settore Ittico. Nuove Frontiere DeLla Responsabilità Sociale D'Impresa. Available online: https: / / www.pesceinrete.com/licenza-sociale-a-operare-nel-settore-ittico-nuove-frontiere-della-responsabilita-socialed-impresa / (accessed on 3 January 2021).

89. Benoît, C.; Norris, G.A.; Valdivia, S.; Ciroth, A.; Moberg, A.; Bos, U.; Beck, T. The guidelines for social life cycle assessment of products: Just in time! Int. J. Life Cycle Assess. 2010, 15, 156-163. [CrossRef]

90. Dreyer, L.C.; Hauschild, M.Z.; Schierbeck, J. Characterisation of social impacts in LCA. Part 1: Development of indicators for labour rights. Int. J. Life Cycle Assess. 2010, 15, 247-259. [CrossRef]

91. L'Abbate, P. Una Nuova Economia Ecologica. Oltre il Covid-19 e il Cambiamento Climatico, 1st ed.; Edizioni Ambiente: Milano, Italy, 2020; ISBN 88-6627-286-8.

92. Beltramello, A.; Haie-Fayle, L.; Pilat, D. Why New Business Models Matter for Green Growth; OECD Publishing: Paris, French, 2013.

93. European Commission. Blue Growth: Opportunities for Marine and Maritime Sustainable Growth; European Commissions: Brussels, Belgium, 2012.

94. International Institute for Sustainable Development. Effects of the Circular Economy on Jobs; International Institute for Sustainable Development: Winnipeg, MB, Canada, 2020.

95. Küçüksayraç, E.; Keskin, D.; Brezet, H. Intermediaries and innovation support in the design for sustainability field: Cases from the Netherlands, Turkey and the United Kingdom. J. Clean. Prod. 2015, 101. [CrossRef]

96. Dayton, P.; Thrush, S.; Agardy, M.T.; Hofman, R. Environmental effects of marine fishing. Aquat. Conserv-Mar. Freshw. Ecosyst. 1995, 5, 205-232. [CrossRef]

97. Stefánsson, G.; Kristinsson, H.; Ziemer, N.; Hannon, C.; James, P. Markets for Sea Urchins: A Review of Global Supply and Markets; Matís: Reykjavik, Island, 2017.

98. Coes, D.H. Critically Assessing the Strengths and Limitations of the Business Model Canvas. Master's Thesis, University of Twente, Twente, The Netherlands, 2014.

99. Bocken, N.; Short, S.; Rana, P.; Evans, S. A value mapping tool for sustainable business modelling. Corp. Gov. Bingley 2013, 13, 482-497. [CrossRef] 